\title{
Correction to: A New Combination with D-Cateslytin to Eradicate Root Canal Pathogens
}

\author{
Claire Ehlinger ${ }^{1,2,3}$ (1) Pauline Dartevelle ${ }^{1,2,3} \cdot$ Abdurraouf Zaet $^{1,2,3} \cdot$ Yoshihito Kurashige $^{4} \cdot$ Youssef Haïkel $^{1,2,3}$. \\ Marie-Hélène Metz-Boutigue ${ }^{1,3} \cdot$ Céline Marban $^{1,2,3}$
}

Published online: 3 October 2019

(c) The Author(s) 2019

\section{Correction to: \\ International Journal of Peptide Research and Therapeutics https://doi.org/10.1007/s10989-019-09911-6}

The article A New Combination with D-Cateslytin to Eradicate Root Canal Pathogens, written by Claire Ehlinger, Pauline Dartevelle, Abdurraouf Zaet, Yoshihito Kurashige, Youssef Haïkel, Marie-Helene Metz-Boutigue and Céline Marban was originally published electronically on the publisher's internet portal (currently SpringerLink) on August 22, 2019 without open access.

With the author(s)' decision to opt for Open Choice the copyright of the article changed on October 4, 2019 to $($ )
The Author(s) 2019 and the article is forthwith distributed under the terms of the Creative Commons Attribution 4.0 International License (http://creativecommons.org/licenses/ by/4.0/), which permits use, duplication, adaptation, distribution and reproduction in any medium or format, as long as you give appropriate credit original author(s) and the source, provide a link to the Creative Commons license and indicate if changes were made.

Publisher's Note Springer Nature remains neutral with regard to jurisdictional claims in published maps and institutional affiliations.
The original article can be found online at https://doi.org/10.1007/ s10989-019-09911-6.

Claire Ehlinger

cehlinger@unistra.fr

1 Inserm UMR 1121, Biomatériaux et Bioingénierie, 11, rue Humann, 67000 Strasbourg, France

2 Faculté de Chirurgie Dentaire, Université de Strasbourg, 3 rue Sainte Elisabeth, 67000 Strasbourg, France

3 Fédération de Médecine Translationnelle de Strasbourg, 11, rue Humann, 67000 Strasbourg, France

4 Health Sciences University of Hokkaido, Kanazawa 1757, Ishikari-Tobetu, Hokkaido 061-0293, Japan 